\title{
Detection of M. leprae in the skin lesions of the so-called negative cases. Scrutinization of concentration methods
}

\author{
Akira NAGAi, Yutaka MIURA, Soichi SUZUKI \\ (Research Institute for Tuberculosis and Leprosy, Tohoku University, Sendai) \\ AND SHIRo MAJIMA \\ (Tohoku Shinseien, Miyagi Pref.)
}

Detection of $\mathrm{M}$. leprae in 168 skin samples removed by trepanation from 58 patients negative for bacilli in repeated examinations of 3 to 8 times in the periods ranging from $1 / 2$ to 2 years was performed. In addition, 6 cases showing occasionally positive, and 17 cases showing $2+$ to $3+$ positive for bacilli were examined similarly. These skin pieces were smeared directly or after trituration and grinding (40 samples of 27 cases) on slides and examined. For the purpose of concentration of bacilli in the tissue, two techniques were employed, $\mathrm{NaOH}$-(with and without acetic acid treatment) and chloroform-methods. The results obtained were summarized as follows :

1) The trepan-snip method seemed to be slightly superior to the routine slit method so far as the 168 samples concerned. However, 3 out of the skin samples showing positive for bacilli, very few in number, by slit method, gave negative results.

2) Smearing preparation after grinding the skin piece in a mortar did not work only unfavorably for search of M. leprae, but also made it difficult presumably because of increase in masking effect of tissue debris on bacillary bodies which would be gradually losing their acid-fastness.

3) Concentration procedure with $\mathrm{NaOH}$ chloroform was unlikely serviceable to the purpose of detecting M. leprae in the skin smaples of very small amount with scanty bacilli.

4) From these results, it can be safely stated that the routine snip or scraping method is a fairly good means for detection of M. leprae. The method is quite simple, practical and suitable for repeated examinations. In addition, the yield is not necessarily inferior in efficiency to snip method, if care is taken for selection of the site to be examined, and for preparation of films after rendering the site bloodless by pressure.

5) Varied changes in morphological and tinctorial properties of $M$. leprae were observed; viz., granular form ( 5 cases), shortening of bacillary body (1), purplish red (3) or pale bluish staining (1), etc. The meaning of these changes remains to be solved by further research.

6) The instruments to be used should be kept quite sanitary. Cleaning of the knife, and other instruments, mortar and pestle, etc. in a boiling $\mathrm{NaHCO}_{3}$-solution is very simple and satisfiable for washing out adhering acid-fast germs to them. 


\title{
いわゆる菌㓌性者における癩菌の検出とその手技の検討
}

\author{
永井彰・三浦裕・鈴木壮一 \\ （東北大学抗酸菌病研究所） \\ 馬嶋四郎 \\ （東北新生園） \\ （受付1966年10月17日）
}

\begin{abstract}
緒論
化学療法の進歩により瀬患者の症状が著しく軽快し, リハビリテーションの問題が大きくとり上げられるよう になった。言うまでもなく, 治癒の判定に最も重要なの は, 患者, 殊に, その皮疹加癩菌を検出するにある。 瀬菌は培養できないので, 結局, 皮膚組織の塗抹標本を 作って鏡検するほかはない。乙れには従来から患者皮膚 に小切を加えて狳抹標本を作る方法が慣用されている が, 検査すべき部位の啦択の他, 標本の染色法や鏡検の 精粗が問題となる。それらはしばらくおき, 先づ, 重要 な被検材料の採取法と集菌法について検討を加えたの で，以下とれについて述べよう。
\end{abstract}

\section{材料と方法}

被検患者 : 主として東北新生園収容の患者と抗酸菌病 研究所外来の患者である。通常の塗抹法による検査で, こ>半年以上 2 年余に亘る数回, 10数回の検査にか〉わ らず, 菌が検出できなくなったもの58例についてトレパ ン採取法による検査を行った。1 人で $1 \sim 5$ ケ所の皮面 より皮片を採取したので，その総数は 168 個に達する。 そのうち 47 例は病歴及び現在の症状から極めてよく吸 収された陳旧癩腫瀬, 若しくはその経過者 (burnt out cases）之診断され，いわゆる，二次的神経癩に相当する 例で, 鼻汁中に癩菌を証したものはなかった。但し 3 例 で鼻汁中に大小の太い抗酸性桿菌の $3 \sim 5$ 個を散在性に 認めた場合があったが，その形から癩菌とは言い難かっ た。結核様癩経過者は 6 例で, 内 2 例はかなり吸収され たがなお淡紅褐色斑をとどめ，2例ではや>明らかな， 残りの 2 例では微かな各瘢痕を残していた。いわゆる純 粋な神経型にいれるべきものは 2 例で, その他境界群, 反応性結核様癩，急性浸潤（組織像は結核様）の鎮静期 の各 1 例となる。臨床所見やレプロミン反応の成績は, 菌の検出との関連で重要且つ興味ある処であるが，こ〉
ではこれ以上この問題には触れない。以上の他, 菌陽性 者, 即ち, 僅数の菌を時折証明できるもの 6 例, $1 \sim 2$ 十内外の菌が常に容易に証明できるもの11 例, 計 17 例 のL型患者む参考に供せられた。

標本の採取 : $2 \mathrm{~mm}$ 径のトレパンを用いて, 予じめ, 沃丁, 酒精, 湯で消毒清拭した検査部皮膚 (2 mg 内外) を皮下に達するまでくり抜くようにして切取った。その 際, ピンセットで切除部周囲の皮䖉をや〉広くつまみ, トレパン, 次いで鏯で手早く切りとり, 血液の附着をで きるだけさける様にした。材料が多いほど菌の検出率も 一般に増すと思われるからである。殆ど麻酔を必要とし ないし, 傷の縫合む不要で, 小ガ一ゼをあて, 絆創骨で しっかりとめておけば事足り, 一時に数ケ所の検査は勿 論, 時を隔てて幾回か検査を反覆するのも容易である. 材料の採取は, 原則として以前に結節や浸潤が著明であ った部分で行い, その他耳楊, 眉の上侧方, 前膊, 下腿 の未端部等も好んで択ばれた。

標本の作製：大別すると次の 4 通りになる。新しい, 而も, 滅菌した清浄なスライド硝子の一面を用時火熖に かざし, 冷した後,

1）その部位に採取皮片の断端を充分になすりつける か, 軽く押しつけて, 所謂, スタンプ標本を作る（スタ ンプ・塗抹一一仮称)。

2）採取皮片を清浄な乳鉢中で細切し，すりつぶした あのを塗抹する（すりつぶし塗抹）。

3）細切した採取組織片に $1 \sim 2.5 \mathrm{~N} \mathrm{NaOH}$ 液の 0.5 $\sim 1 \mathrm{ml}$ を加えて眔濁液を作り, $37^{\circ} \mathrm{C}$ に 30 分放置後, 塩 酸水を加えて全体を冷却しながら中和し, 数倍量の水を 加えて攪拌し, $3,000 \mathrm{rpm}$ で 30 分遠心し, 上清の大部分 を棄て, 沈渣の最上面を塗抹し, 更に食塩水を加えて惩 濁液を作り，スライドに塗抹した。(2) 及び (3) の材料 は小川培地に塗抹して培善試験 $\left(37^{\circ} \mathrm{C}, 28^{\circ} \mathrm{C}\right)$ に供した (苛性ソーダ法)。 
4)細切した皮片を Dharmendra 抗原作製法3になら いクロロホルムで抽出するか, 又は, Kar et al. ${ }^{7)}$ の方 法に準じて，皮片を直ちに $2 \%$ 醋酸水に投じ 1 ～時 間後, 軟化膨潤した材料から上皮だけ除くか, 又は, そ のま〉乳鉢でよくすりつぶし，小量の生理的食塩水に㲘 濁し, クロロホルムを 1 滴加えて $3,000 \mathrm{rpm}, 30$ 分遠 心し, クロロホルム層 (下) と生理的食塩水層（上）の 境界にある粒子層をピペットで吸ひ取り，スライドに塗 抹, 染色する(クロロホルム法)。

標本に見出される菌の形態について：乙れについは化 学療法之の関連むあり, 形, 染色共に良好なもの (solid), 形はよいが染色が極めて不良のもの，又は，形が崩れて 顆粒状になったもの (non-solid), など色々の変状が知 られている。てれらを常に明確に癩菌と同定するてとは 時によって簡単でないとともある。それらが数が少く, 而あ, 同じ標本内に形のよい癩菌が見出せない場合は一 層難かしい。我々の場合も, 時にか〉る崩壊に傾した菌 に接したが, 多くは桿菌状のものと共存していた。抗酸 性顆粒のみが見られた場合が 5 例, 極めて短い桿菌のみ の場合が 1 例, 染色が不良で紫紅色を呈する菌のみの場 合が 3 例, 青染した菌のみの場合が 1 例づつあった。そ の他, 瀬菌と考えて間違いない桿菌と共にこれらの不良 菌が共存した例はかなり見られたが，そのうち青染し た桿菌をかなり混えていた例は 4 例あり，いわゆる， segmented の桿菌を混じたものもあり，1例ではかな り多かった。菌の染色及び形態の変化と臨床所見, 経過 との関連は仔細に見ると複雑なものがあり, 注意して観 察すると病勢がなお衰え結節中の菌にもかつる变化に 陥った菌が見られる。いづれにしても, 興味ある問題で 稿を改めて論ぜねばなるまい。なお, 鼻汁内菌陰性の10 例（内 7 例は snip 法又は集菌法で少数の菌を皮疹内に 証明）で, 鼻粘膜を鋭匙でかきとり塗抹標本を作って検 したが癩菌を証明したものはなかった。

検査用器具の清浄化について : 最後に, 最も注意すべ きととに, 検査に用いる器具の清浄化がある。トレパン や鋏, ピンセットは充分磨粉で清拭し, 先端は酒精に浸 し, 少時火㷔にかざすのがよい。乳鉢と乳棒とは最も警 戒すべきもので，磨粉と石鹼による清拭では抗酸菌の附 着は除き得ない。遠心沈測管，ピペット，スライド硝子 等は重クローム硫酸中に 1 夜以上浸漬する。1 度菌検査 に用いた器具は, 石鹼, 磨粉, アルコール, クロロホル ム, エーテル等での洗涤では次の用に供し得ないと心得 るべきで, 金属器具では焼灼するか, $160^{\circ} \mathrm{C} 3 \sim 6$ 時間 乾熱滅菌する要がある。特に, 癩菌以外の抗酸菌を扱っ
ている研究室では, 清拭には慎重の上にも慎重を期さね ばならない, 凡て, 器具は $5 \%$ 重曹水で煮沸し, 石鹼水 で充分洗條する方法が簡単で確実であることを後で知っ た。

\section{成 績}

先づ, 単純塗抹法で (slit 又は scraping) で, 簡単に 菌が発見できる癩腫瀬皮疹 $(+2 \sim+3)$ 約 20 個をトレパ ンで採取し, 以上の方法で鏡検するなら全例で多くの菌 を見るのは当然で，殊に，集菌法ではしばしば菌が集塊 を作って見られる。即ち, slit 法よりも小皮膚片を採取 するトレパン法, 即ち, snip 法の方がより多くの菌が検 出でき, 集菌法を施せば一層多くの菌が発見されると思 われた。併し, 菌のきわめて少い材料についてはこうは いかなかった。

1）トレパン採取皮片から塗抹乃至スタンプ標本を作 った場合（トレパン・スニップ法）

イ）半年以上数年も連続して皮表より菌が証明できな かった前述58例で，その168個の皮疹で調べたら更に10 例，13ケ $(7.8 \%)$ がこの方法で菌陽性となった。即ち, 通常の slit 法よりや〉優るように見えた。とてろが

口) 通常塗抹法 (slit 法) では菌の証明がかなり困難 だが，時に，2，3 ケ程度の少数の菌が見出されるよう な症例 6 人の 15 ケの材料でトレパン・スニップを行った 所，わづかにその 2 例 3 個の皮疹で菌陽性だったにすぎ ず，菌の少い材料では必ずしもトレパン・スニップ法が slit 法にまさるとは言えなかった。もとより検査部位が 同じではなく検査の時期にもズレがあったから，その比 較は無理で, 検査部位の選択と検査の精粗が最も問,題に なるとは言え案外の成績であった。

2）集菌法による成績

イ）トレパン採取皮片を乳鉢で充分すりつぶした場合 (すりつぶし法)

27例で 40個の材料で検したところ，そのうち4例 4 ケ (10\%) に陽性と言う悪い成績で, スタンプ塗抹の成績 よりずっと不良であった。

口) $\mathrm{NaOH}$ 集菌法（苛性ソーダ法）

前述, 皮片をすりつぶしてから苛性ソーダで処理した 分を含めて，56例 78個 (殆ど L 型で 9 例 9 ケの $1+\sim 2+$ 菌陽性例を含む）の皮疹でこの方法を実施した。それに よると，6例 6 個 $(7.7 \%)$ の陰性皮片が更に菌陽性之な った。すなわちすりつぶしてから $\mathrm{NaOH}$ の処理をした 分は 21 例 33 個であるが， 2 例 2 ケだけが菌陽性となっ た。而るに, スタンプ塗抹, 若しくは,「つぶし」法で 
Table 1. Results of bacillary findings observed in 78 skin samples of 56 cases by concentration technique with $\mathrm{NaOH}$

\begin{tabular}{|c|c|c|}
\hline $\begin{array}{l}\text { Changing of bacillary findings before and } \\
\text { after concentration procedure }\end{array}$ & \multicolumn{2}{|c|}{ Number of } \\
\hline $\begin{array}{c}\text { Before } \\
(\text { slit and snip }) \rightarrow(\text { concentration })\end{array}$ & patients examined & $\begin{array}{l}\text { skin lesions examined } \\
\text { (per cent) }\end{array}$ \\
\hline$(-) \rightarrow(-)$ & 28 & 50 \\
\hline$(-) \rightarrow(+)$ & 6 & $6(7.7 \%)$ \\
\hline$(+) \rightarrow(-)$ & 13 & $13(16.6 \%)$ \\
\hline$*(+) \rightarrow(+)$ & 9 & 9 \\
\hline & 56 & 78 \\
\hline
\end{tabular}

* Cases showing occasionally positive for M. leprae, though a few in number, in skin lesions.

Table 2. Results of bacillary findings observed in 45 skin samples of 40 cases by concentration technique with chloroform

\begin{tabular}{c|c|c}
\hline $\begin{array}{c}\text { Changing of bacillary findings before and } \\
\text { after concentration procedure }\end{array}$ & \multicolumn{2}{|c}{ Number of } \\
\hline $\begin{array}{c}\text { Before } \\
\text { (slit and snip) } \rightarrow \text { (concentration) }\end{array}$ & patients examined & $\begin{array}{c}\text { skin lesions examined } \\
\text { (per cent) }\end{array}$ \\
\hline$(-) \rightarrow(-)$ & 25 & 30 \\
$(-) \rightarrow(+)$ & 4 & $4(8.9 \%)$ \\
$(+) \rightarrow(-)$ & 2 & $2(4.4 \%)$ \\
$*(+) \rightarrow(+)$ & 9 & 9 \\
\hline
\end{tabular}

* Cases showing occasionally positive for M. Leprae, though a few in number, in skin lesions.

菌陽性だった 13 例 13 ケの皮疹では本集菌法によってか えって全例が陰性となったのが注目された。併し $2+$ 程 度の菌陽性皮片 9 例では全例菌陽性に変りがなかった。

(第 1 表)。

八）クロロホルム集菌法

40 例 45 個（内 9 例は $1+\sim 2+$ の菌陽性者）で行った が，菌陽性者 4 例を増し，反対に slit 陽性の 2 例が却っ て陰性化した。2+菌陽性者は全例菌陽性に変りがなか った（第 2 表）。

結局, $\mathrm{NaOH}$, クロロホルム両集菌法を延べ 96 例 123 ケの皮疹で行ったが，乙れら集菌法によって新たに菌が 検出された場合は，8\%内外で以外に成績が悪く, 殊に, $\mathrm{NaOH}$ 法ではスタンプ塗抹 (snip) 法で陽性だった皮片 の $16 \%$ が菌陰性と化したのは以外であった。即ち, 含 有菌数が微量な場合，小さい皮海片について集菌法を行 うことには無理があり，薬剂処理による抗酸性の低下， 操作中の菌の流失, 組織片による隐蔽が大きく影響する と思われる。

\section{考按}

皮屑の癩腫（結節）から癩菌を証明することは，一般 に甚だ簡単で何の工夫も要しない。併し，不定群皮疹， 結核様皮疹や吸収に顈した癩腫性疹では，乙のことは必 ずしも容易でなく，時に殆ど不可能でさえある。病勢が 停止消失し, “burnt out” の状態となり, 年余に亘つて 反覆検査しても菌が検出できなくなったような症例，即 ち, いわゆる, arrested cases では, 更に, この状態が 1 年以上続けば, 軽快若しくは臨床的治癒と考えて実際上 まづ差支えなかろうと言うのが1966年 4 月，高松の第39 回麻学会での癩研究協議会の「治瘾判定基準」シンポジ ウムの ${ }^{17)}$ の決議的見解でああった。癩菌の培養ができな い以上, 止むを得措置である。即ち, 瀬の治癒判定に 最も大切な基準は，瀬菌の検出にあることは言うまでも ない。このため従来より色々の措置が取られた。1933年 のマニラの国際嬾会議(6)では，標準法として, scraping （皮䖉に小切を加え割面内面を塗抹する）と $\operatorname{snip}(2 \mathrm{~mm}$ 
位の樑さに皮部を剪みとって塗抹を作る）の 2 方法をあ げたが，先に Lowe ${ }^{10)}$ の言った slit 法と clip 法がそれ に当る。Wade $\left.{ }^{14}\right)$ は皮疹よりの菌検査の方法を詳細に論 じ, incision (小切開) と $\operatorname{sip}$ (小皮片の採取) の両法を あげ, 前者が実際上最も簡単でその効率も後者に劣らな いと述べ，少くとも $2 \mathrm{~mm}$ 以上の深さまで割を加えるこ と, 被検部はよく拭き, 癩菌以外の抗酸菌の混入を避け るため表皮面は塗抹せ女とと, 何にも增して器具の清拭 が大切だから刃物は酒精に浸して火㷔にかざすべきてと （灼くのではない）などの注意を述べた。同氏によると,記 録に残っている snip 法は Alvarez1) (ハワイ)のものが 最初であると言う。Arnold2) とよると, Souza Araujo13) は pean などで皮面をつまみ, 局処の乏血を起させてお いて, 太い注射針で 2〜3 ケ所から淋巴を集めて塗抹検 鏡する方法がよく, Wade ${ }^{15)}$ の scraping incision にはる かに優ると述べたと言う。Figueredo et al.5) は snip 法 変法を推奖した。Muir ${ }^{12)}$ その著で slit, snip, puncture 及び cutting puncture の 4 法をあげた。 Maddock ${ }^{11)}$ は安 全カミソリの刃で回転しながら割を入れる法で arrested cases の84例中 19 例で菌を証したと言う。その後, 略時 を同じうして, 印度からてれに関し 3 つの集菌法が発表 された。煩を顧みず紹介すると，

1) Figueredo et al.6) の法: 切除皮片 (3 mm) を試験 管に入れ，2.5\% アセトンにクロロホルム $2.5 \mathrm{cc}$ を加え て 4〜5 時間置いてから硝子棒でつぶしつ〉抽出し, ク ロロホルムを温浴中で数滴になるまで蒸散し, 冷却後, $5 \mathrm{cc}$ のエーテルを加えて 3,000 回転 15 分遠心し, 管底に 数滴を残してエーテルを蒸散せしめ, スライド上に塗抹 し, 更に, 遠沈管を数㵜のエーテルで洗って追加塗抹 し, carnoy 液でてれを固定して染色鏡検する集菌法で ある。染色はチール氏液10分, 弁色は $10 \%$ 塩酸で行う。 同氏等はこの方法で 48 例の瀨患者接触者 (contact) 中そ の31例の皮膚に菌を証したと言う。

2) Dharmendra et al. 1) の法: クロロホルムで皮片 を抽出し, 同じくその塗抹標本を carnoy で固定する集 菌法である。同氏等の言う neuromacular 症例の 53例中 51例までに菌を証明したと言う。

3) Khanolkar et al. 法8,9): 皮片 $(5 \times 3 \times 5 \mathrm{~mm})$ を $1 \%$ 醋酸水中に 4-8 時間浸漬し, 表皮を除去した残りを 硝子製の Potter 型ホモジナイザーで 2,000回転5 10 分 かけ，管壁の組織屑を $1 \%$ 醋酸水で洗い落し, 全量を $5 \mathrm{cc}$ とし, 石油エーテルと硫酸エーテルの $1: 10$ 混合液 20 滴をてれに加え, 強く振盜しつつ湿和し, そのま〉 15〜20 分間管を立てたま >放置し, 次に $10 \mathrm{cc}$ の蒸留水
を管壁を洗い落しながら加えると，2〜5 分後に液面に 白色又は琥珀色の輪状の首がでるからてれをスライド に塗抹して染色鏡検する。弁色には $33 \%$ 塩酸を使い, 復染色には薄めた azur II を用いた。同氏等はての方法 で, 通常の方法では証明できなかった神経型から採った 100 例を越える皮膚片で，菌を証明することができたと 言う。最近, Kar et al. ${ }^{7)}$ の発表した研究室外集菌法 は, 皮片 $(2-4 \mathrm{~mm})$ を $0.4 \mathrm{cc}$ の醋酸 $(2 \%)$ 亿入れ表皮 を去り,つぶして, 上清を捨て, 微量のクロロホルム $(0.04 \mathrm{cc})$ を加えて 3 分間振り， $1,000 \mathrm{~g}$ で 10 分間遠心 し, 上清は去って沈渣を塗抹する。乙の方法で, 通常法 では 5 例しか陽性でなかった 31 例の, 所謂, “burnt out” cases の 21 例までが陽性になったと言う。以上が菌検査 法に就ての先人研究の跡で, 我々の研究も凡そ乙れにな らったもので, トレパンにより比較的大量の材料を容易 に採取し, 組織中の菌をできるだけ多く遊離せしめて集 め, 検出率の向上をはかったものである。例数が少く, 検査の時期や最も大切な検査部位が同一でないから, 直 ちに比較するのは無理であるが Lowe ${ }^{10}$ ) の報告にあある ように snip 法は通常の塗抹法, 即ち, slit 法に多少優る 成績を獲たがこれとて通常の塗抹処理を充分叮寧にやる なら, 両者の成績に大差がなかったのではないかと思わ れ, 現に slit 法で極めて僅かの菌を見た 6 例が snip 法 で 3 例陰性化したのをみた。又,トレパンで採取した皮 片を乳鉢で充分すりつぶして㙦抹する方法も意外飞悪 く, 却って, 陰性率の著しい低下を来したが，乙れは, 弱った菌を器械的に崩壊せしめ抗酸性が失われる, 余分 の組織片で masken される, 操作中に流出する, とかの 理由によるのかむしれ妵菌法に至っては, 菌の比較 的多い材料では一層有効と思われるが, 今問題としてい るような菌が弱って居り, 且つ, 極めて少い材料では案 外芳しくなく, 多少陽性率の向上を来しても $(7.7 \%)$, その反面, スタンプ塗抹陽性 (少数菌) 例が陰性化する 傾向があり, 殊に, それは $\mathrm{NaOH}$ 法で極めて著しく20 \%にも達した。最後に, 検査器具を清浄にすること办最 も重要であることを強調し，乙れには，5\% 重曹水の煮 沸処理が最も簡単で有効なととを強調したい。

\section{結 論}

1） 6 ケ月乃至 2 年余に亘る数回の検査にも, 菌办陰 性であった症例について，168個の皮疹を $2 \mathrm{~mm}$ のトレ パンで採取し, 塗抹法と集菌法 $(\mathrm{NaOH}$ 及びクロロホル ム法）とにより癩菌の検出を試みた。

2) 皮片採取塗抹法（snip）は小切開（slit）法より多 
少優るようであるが, 後者を叮寧に行えば実際上, 成績 に殆ど差はないと思われる。集菌法は, 材料が余りに小 さいため, 苛性ソーダ法にせよ, クロロホルム法にせ よ, 一方で多少陽性率を增すとしても ( $10 \%$ 以下), 他 方では却っててれを低下させる。殊に，それは苛性ソー ダ法で著しい。即ち, 手技の繁雑な割に効果は少い。結 局, 真皮より皮下にかけての組織を充分に塗抹するな ら, slit (scraping) 法, 即ち, 慣用の塗抹作製法が簡単 で実用に適し, 効果もトレパン（snip）法や集菌法に劣 るものではない。

4) 器具の清净化には $5 \%$ 重曹水煮沸洗沙が最も簡単 で有効である。

\section{文献}

1) Alvarez: cited by Wade in (14)

2) Arnold, H. L., Jr.: Modern concepts of leprosy. Springfield, U.S.A. 1953, p. 34

3) Dharmendra: Studies of the lepromin test. (9) A bacillary antigen standardized by weight. Lep. India, 14, 121 (1942)

4) Dharmendra and N. Mukerjee: A simple method of concentration of leprosy bacilli from "closed" cases of leprosy. Lep. India, 24, 169-177 (1952)

5) Figueredo, N. and S.D. Desai : Positive bacillary findings in the skin of contacts of leprosy patients. (Reprint.) Intern. J. Lep., 18, 59-66 (1950)

6) Figueredo, N. and S.D. Desai : A new method for the detection of leprosy in neural cases and contacts. Indian J. Med. Sci., 6, 296-301 (1952); (abst.) Intern. J. Lep., 21, 128 (1953)

7) Kar, S., E.P. Elliston and C.E. Taylor: Field method for concentrating Mycobacterium laeprae in skin leprosy specimens. Intern. J. Lep., 32, 18-23 (1964)

8) Khanolkar, V.R.: A concentration method for acid-fast bacilli in skin biopsies from leprosy patients. Lep. Rev., 23, 133-138 (1952)

9) Khanolkar, V.R. and K. Rajalakshmi: A method for concentration of aicd-fast bacilli in skin biopsies from leprosy patients. Lep. India, 24, 47-61 (1952)

10) Lowe, J. and E.B. Christian : Bacteriological examination in leprosy. Indian J. Med. Res., 19, 867 (1932)

11) Maddock, R.K.: Skin scrapings in leprosy; positive results by the Wayson technique in 84 supposedly arrested cases. J. Amer. Med. Assoc., 148, 44-45 (1952)

12) Muir, E. : Manual of leprosy. E.S. Livingston, Ltd. 1948, p. 84

13) Souza Araujo: cited from Arnold in (2)

14) Wade, H.W.: The bacteriological examination in leprosy. Lep. Rev., 6(2), 2-8 (1935)

15) Wade, H.W. : Skin scrapings in leprosy. (Corres.) J. Amer. Med. Assoc., 149, 1595 (1952)

16) [Manila Congress]: Intern. J. Lep., 1, (1933)

17） [第39回 日本癩学会総会特別報告] 癩病勢並治瘾 判定基準, レプラ, 35, 100-103 (1966) 